\title{
Comparative Electrochemical Fluorination of Ethanesulfonyl Chloride and Fluoride
}

\author{
N. Ignat'ev, ${ }^{a, *}$ A. Kucherina ${ }^{a}$ and P.Sartori ${ }^{b, *}$
}

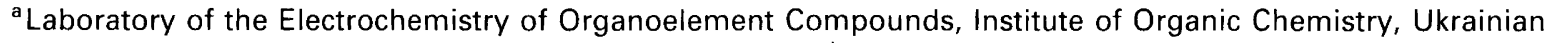
National Academy of Sciences, $253094 \mathrm{Kiev}$, Ukraine and ${ }^{\mathrm{b}}$ Institut für Synthesechemie, Gerhard-Mercator-University of Duisburg, Lotharstrasse 1, D-47048 Duisburg, Germany

\author{
Dedicated to Professor Henning Lund on the occasion of his \\ 70th birthday.
}

\begin{abstract}
Ignat'ev, N., Kucherina, A. and Sartori, P., 1999. Comparative Electrochemical Fluorination of Ethanesulfonyl Chloride and Fluoride. - Acta Chem. Scand. 53: 11101116. (c) Acta Chemica Scandinavica 1999.

Comparative electrochemical fluorination (ECF) of ethanesulfonyl chloride and fluoride via the Simons process has been investigated. In contrast to previously reported data, the electrochemical fluorination of $\mathrm{C}_{2} \mathrm{H}_{5} \mathrm{SO}_{2} \mathrm{Cl}$ only results in low yield of $\mathrm{C}_{2} \mathrm{~F}_{5} \mathrm{SO}_{2} \mathrm{~F}$ and the observed product distribution pattern indicates the strong influence of the chlorination process on the decomposition of the starting material. Ethanesulfonyl fluoride serves as a suitable starting material for the high-yield syntheses of pentafluoroethanesulfonyl fluoride and pentafluoroethanesulfonic acid. The electrochemical reduction of alkane- and chloroalkane-sulfonyl chlorides was investigated by cyclic voltammetry in order to explain the behaviour of these compounds during the Simons process.
\end{abstract}

The electrochemical fluorination (ECF, the Simons process) in anhydrous $\mathrm{HF}$ (aHF) has proved to be a powerful method for the conversion of non-fluorinated and partially fluorinated organic compounds into perfluorinated ones. ${ }^{1}$ Since its discovery at the beginning of the 1940 s, this method has been widely applied to the fluorination of organic compounds containing $\mathrm{C}-\mathrm{C}$, $\mathrm{C}-\mathrm{O}, \mathrm{C}-\mathrm{S}, \mathrm{C}-\mathrm{N}, \mathrm{C}-\mathrm{P}$ and $\mathrm{S}-\mathrm{N}$ bonds. ${ }^{2}$ The Simons process is a one-step electrochemical synthesis of perfluorinated organic compounds, and it is successfully used for the large-scale industrial production of important fluorochemicals, such as triflic acid (trifluoromethanesulfonic acid). The first step in the production of triflic acid is the electrochemical fluorination of methanesulfonyl chloride in anhydrous HF using nickel electrodes, eqn. (1). This process results in the formation of trifluoromethanesulfonylfluoride in a good chemical and current yield. ${ }^{3}$

$$
\mathrm{CH}_{3} \mathrm{SO}_{2} \mathrm{Cl} \underset{\mathrm{HF}}{\stackrel{\mathrm{e}, \mathrm{Ni}}{\longrightarrow}} \mathrm{CF}_{3} \mathrm{SO}_{2} \mathrm{~F}
$$

Recently much interest has also arisen in pentafluoroethanesulfonic acid and some of its derivatives, primarily

\footnotetext{
* To whom correspondence should be addressed.
}

in bis(pentafluoroethylsulfonyl)imide, for application as a lithium salt in lithium ion batteries.

In principle pentafluoroethanesulfonic acid can be produced in the same way as triflic acid starting from ethanesulfonyl chloride. The ECF of this material was carried out by Gramstad and Haszeldine in $1957 .{ }^{4}$ They claimed a $79 \%$ yield of the corresponding pentafluoroethanesulfonyl fluoride. All our attempts to reproduce this yield of pentafluoroethanesulfonyl fluoride by means of ECF of ethanesulfonyl chloride have failed, which stimulated us to undertake a comparative study of the electrochemical fluorination of ethanesulfonyl chloride and ethanesulfonyl fluoride.

\section{Experimental}

Stainless steel Simons-type electrochemical cells (Fig. 1) of different volumes were used for the ECF of ethanesulfonyl chloride and ethanesulfonyl fluoride. Each cell was equipped with a stainless steel condenser to condense the HF vapours.

Ethanesulfonyl chloride ( $\geqslant 98 \%$, Fluka) and hydrogen fluoride $(\geqslant 99 \%$, Bayer AG) were used without further purification.

Ethanesulfonyl fluoride was obtained in $90 \%$ yield 


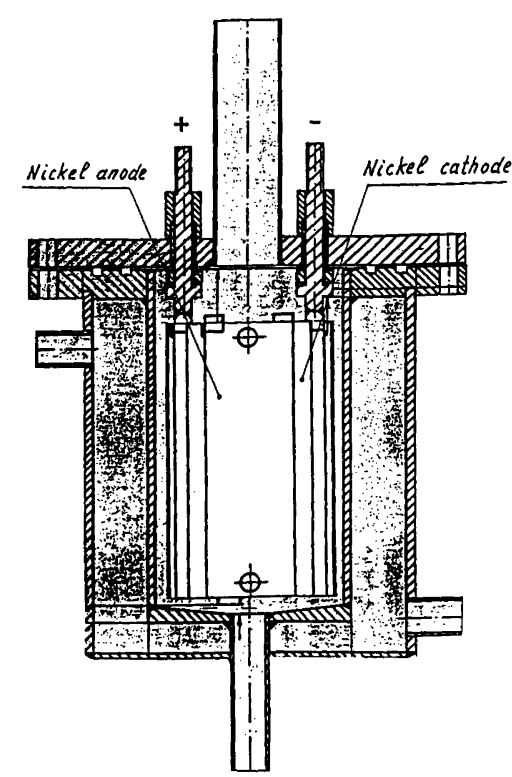

Fig. 1. Electrochemical cell for the Simons process.

from ethanesulfonyl chloride by halogen exchange with potassium hydrogen difluoride.

\section{Electrochemical measurements}

Voltammetric measurements were carried out with a potentiostat from Pyne Co. (USA). Cyclic voltammograms were obtained with a three-electrode system using a glassy carbon disk (i.d. $2.29 \mathrm{~mm}$ ) as the working electrode and a platinum wire as the counter-electrode. All measurements were carried out with a saturated calomel electrode (SCE) as the reference electrode which was adjusted into the cell over a special bridge $\left[E_{\mathrm{p}}^{\mathrm{ox}}\right.$ (ferrocene) $=0.46 \mathrm{~V}$ ] to prevent the diffusion of water into the measured solution.

Acetonitrile (Merck, $\geqslant 99 \%$ ) was distilled twice over $\mathrm{P}_{4} \mathrm{O}_{10}$ and additionally over $\mathrm{CaH}_{2}$ with a 1-m column. Tetrabutylammonium tetrafluoroborate was synthesized and purified as previously described. ${ }^{5}$

Electrochemical fuorination of ethanesulfonyl chloride. (a) A cylindrical cell (total volume $360 \mathrm{~cm}^{3}$ ) with an array of nickel anodes (effective anodic area, $S=4.58$ $\mathrm{dm}^{2}$ ) and cathodes with the same effective area was used for this experiment. The temperature of the cell body was maintained at $-1^{\circ} \mathrm{C}$, and the temperature of the condenser was kept at $-30^{\circ} \mathrm{C}$. Ethanesulfonyl chloride $(136.4 \mathrm{~g} ; 1.06 \mathrm{~mol})$ was added in 12 portions $(11.5 \mathrm{~g}$ at the beginning; $10.2 \mathrm{~g}$ after $28.6 \mathrm{~A} \mathrm{~h} ; 10.8 \mathrm{~g}$ after $55.9 \mathrm{~A} \mathrm{~h}$; $15.0 \mathrm{~g}$ after $81.9 \mathrm{~A} \mathrm{~h} ; 9.6 \mathrm{~g}$ after $123.4 \mathrm{~A} \mathrm{~h} ; 15.9 \mathrm{~g}$ after $144.0 \mathrm{~A} \mathrm{~h} ; 9.0 \mathrm{~g}$ after $184.1 \mathrm{~A} \mathrm{~h} ; 13.2 \mathrm{~g}$ after $205.7 \mathrm{~A} \mathrm{~h}$; $10.4 \mathrm{~g}$ after $239.9 \mathrm{~A} \mathrm{~h} ; 13.7 \mathrm{~g}$ after $266.3 \mathrm{~A} \mathrm{~h} ; 12.1 \mathrm{~g}$ after $301.4 \mathrm{~A} \mathrm{~h} ; 5.0 \mathrm{~g}$ after $327.7 \mathrm{~A} \mathrm{~h}$ ) to $306 \mathrm{~g}$ of liquid hydrogen fluoride previously electrolysed in the cell during $48 \mathrm{~h}$ at a cell voltage of 4.9-5.2 V. The gaseous products from the cell were passed through a condenser and two FEP traps at $-78^{\circ} \mathrm{C}$. The electrolysis, which proceeded at a cell voltage of $4.9-5.3 \mathrm{~V}$ and a current density of $0.47-0.55 \mathrm{~A} \mathrm{dm}^{-2}$, was finished after consumption of $378 \mathrm{~A} \mathrm{~h}$ ( $110.9 \%$ of the theoretical amount of electricity). During the electrolysis, the amount of liquid in the cell was kept constant by occasional addition of hydrogen fluoride. The liquid product collected in both traps was separated from the HF layer and examined by ${ }^{19} \mathrm{~F}$ NMR at $-40^{\circ} \mathrm{C}$ using a tightly closed NMR tube made from FEP. This tube was sealed with Parafilm and placed inside a glass sleeve containing acetone- $\mathrm{d}_{6}$ and standard $\left(\mathrm{CCl}_{3} \mathrm{~F}\right)$ for NMR measurements.

Altogether $35 \mathrm{~g}$ of fluorinated material was obtained.

(b) This experiment was carried out in the same cell as the experiment (a), but the temperature of the cell body was maintained at $5^{\circ} \mathrm{C}$ and the temperature of the condenser was kept at $-15^{\circ} \mathrm{C}$. Ethanesulfonyl chloride ( $107.3 \mathrm{~g} ; 0.83 \mathrm{~mol})$ was added in twelve equal portions every $24 \mathrm{~A} \mathrm{~h}$ to $305 \mathrm{~g}$ of liquid hydrogen fluoride previously electrolysed in the cell during $48 \mathrm{~h}$ at a cell voltage of $5.0-5.2 \mathrm{~V}$. The electrolysis proceeded at a cell voltage of 4.4-5.3 V with a current density of $0.44 \mathrm{~A} \mathrm{dm}^{-2}$ and was finished after $356.7 \mathrm{~A} \mathrm{~h}$ of electricity were consumed (132.8\% of the theoretical amount of electricity). The liquid product $(39 \mathrm{~g})$ was collected in the traps in the same way as in the previous experiment. After the distillation of this material and washing in the vapour phase at room temperature with water and concentrated sulfuric acid, $32 \mathrm{~g}$ of a liquid containing $85 \%$ of $\mathrm{C}_{2} \mathrm{~F}_{5} \mathrm{SO}_{2} \mathrm{~F}$ (yield $16 \%$ ) was isolated. After hydrolysis of this material with $\mathrm{Ba}(\mathrm{OH})_{2} \cdot 8 \mathrm{H}_{2} \mathrm{O}$, followed by treatment of the $\mathrm{Ba}$ salts with $100 \%$ sulfuric acid, a mixture of $\mathrm{C}_{2} \mathrm{~F}_{5} \mathrm{SO}_{2} \mathrm{OH} \quad(96 \mathrm{~mol} \%)$ and $\mathrm{ClCF}_{2} \mathrm{CF}_{2} \mathrm{SO}_{2} \mathrm{OH}$ $(4 \mathrm{~mol} \%)$ was obtained.

${ }^{19} \mathrm{~F} \quad \mathrm{NMR}, \mathrm{ppm}: \quad-79.7 \mathrm{~s} \quad(3 \mathrm{~F}), \quad-115.9 \mathrm{~s} \quad(2 \mathrm{~F})$ $\left(\mathrm{C}_{2} \mathrm{~F}_{5} \mathrm{SO}_{2} \mathrm{OH}\right) ; \quad-66.8 \mathrm{~s} \quad(2 \mathrm{~F}), \quad-110.1 \mathrm{~s} \quad(2 \mathrm{~F})$ $\left(\mathrm{ClCF}_{2} \mathrm{CF}_{2} \mathrm{SO}_{2} \mathrm{OH}\right)$.

MS for $\mathrm{C}_{2} \mathrm{~F}_{5} \mathrm{SO}_{2} \mathrm{OH}:$ m/e $50\left(\mathrm{CF}_{2}\right), 64\left(\mathrm{SO}_{2}\right), 65$ $\left(\mathrm{SO}_{2} \mathrm{H}\right), 69\left(\mathrm{CF}_{3}\right), 81\left(\mathrm{SO}_{3} \mathrm{H}\right), 100\left(\mathrm{C}_{2} \mathrm{~F}_{4}\right), 119\left(\mathrm{C}_{2} \mathrm{~F}_{5}\right)$, $183\left(\mathrm{C}_{2} \mathrm{~F}_{5} \mathrm{SO}_{2}\right)$.

MS for $\mathrm{ClCF}_{2} \mathrm{CF}_{2} \mathrm{SO}_{2} \mathrm{OH}: m / e 36(\mathrm{Cl}), 85\left(\mathrm{ClCF}_{2}\right)$, $135\left(\mathrm{C}_{2} \mathrm{~F}_{4} \mathrm{Cl}\right), 215\left(\mathrm{M}^{+}-\mathrm{H}^{+}\right)$.

Electrochemical fuorination of ethanesulfonyl fuoride. A cylindrical cell (total volume 1.51) with an array of nickel anodes (effective anodic area, $S=15.6 \mathrm{dm}^{2}$ ) and cathodes with the same effective area was used for the ECF of ethanesulfonyl fluoride. The temperature of the cell body was maintained at $0^{\circ} \mathrm{C}$ and the temperature of the condenser was kept at $-25^{\circ} \mathrm{C}$. Ethanesulfonyl fluoride $(1115.6 \mathrm{~g}$; $9.96 \mathrm{~mol}$ ) was added in 27 portions to $1140 \mathrm{~g}$ of liquid hydrogen fluoride previously electrolysed in the cell during $111 \mathrm{~h}$ at the cell voltage 4.5-5.2 V. The electrolysis proceeded at a cell voltage of $4.8-5.2 \mathrm{~V}$ and a current density of $0.20-0.32 \mathrm{~A} \mathrm{dm}^{-2}$ and was finished after $3492.2 \mathrm{~A}$ h of electricity were consumed $(130.9 \%$ of the theoretical amount of electricity). The liquid product collected in the traps at $-78^{\circ} \mathrm{C}$ was periodically separated from HF which was reused in the cell. Altogether 
$1651 \mathrm{~g}$ of practically pure $\mathrm{C}_{2} \mathrm{~F}_{5} \mathrm{SO}_{2} \mathrm{~F}$ were obtained (yield $82.1 \%$ ). This product was hydrolysed with $\mathrm{Ba}(\mathrm{OH})_{2} \cdot 8 \mathrm{H}_{2} \mathrm{O}$ to $\left(\mathrm{C}_{2} \mathrm{~F}_{5} \mathrm{SO}_{3}\right)_{2} \mathrm{Ba}$ (yield $\left.97 \%\right)$ and later converted into pure pentafluoroethanesulfonic acid (yield $99 \%$ ) using $100 \%$ sulfuric acid.

\section{Results and discussion}

Alkanesulfonyl chlorides are typical starting material for the synthesis of perfluoroalkanesulfonyl fluorides via the Simons process. In many cases it was assumed that during this process the replacement of the chlorine with fluorine in the sulfonyl chlorides proceeds by the action of $\mathrm{HF}$ in a manner similar to that occurring in the case of acyl chlorides. ${ }^{6}$ Contrary to this common opinion, we have recently shown that chlorine in alkanesulfonyl chlorides cannot be exchanged with fluorine simply by dissolving of these substances in aHF (standard media for the Simons process), but is very rapidly replaced by fluorine in the presence of oxidising agents, such as $\mathrm{SbF}_{5}{ }^{2}$ This means that during the ECF in aHF the replacement of chlorine in sulfonyl chlorides proceeds via an oxidative mechanism instead of a nucleophilic substitution. As a result. an S F bond is formed and chlorine leaves the alkanesulfonyl chloride molecule as a radical or as a positively charged species, presumably via the formation of mixed nickel chloro-fluoride intermediates.

The typical cell for the Simons process is an undivided cell. The main cathodic process which takes place during the ECF in aHF is the electrochemical reduction of protons with the formation of hydrogen, eqn (2).

$\mathrm{H}^{+}+\mathrm{e} \longrightarrow \mathrm{H}^{\text {. }}$

In the case of the electrochemical fluorination of alkanesulfonyl chlorides the reduction by cathodically formed hydrogen or the direct electrochemical reduction of the starting material is also possible to some extent [eqns. (3) and (4)].

$$
\begin{aligned}
& \mathrm{RSO}_{2} \mathrm{Cl}+2 \mathrm{H}^{-} \longrightarrow \mathrm{RSO}_{2} \mathrm{H}+\mathrm{HCl} \\
& \mathrm{RSO}_{2} \mathrm{Cl}+2 \mathrm{e} \longrightarrow \mathrm{RSO}_{2}{ }^{-}+\mathrm{Cl}^{-}
\end{aligned}
$$

Chloride anions resulting from this process undergo the following oxidation on the surface of the $\mathrm{Ni}$ anode with the formation of chlorine radicals and finally $\mathrm{Cl}_{2}$. As a result, the liquid phase trapped at $-78^{\circ} \mathrm{C}$ during the $\mathrm{ECF}$ of methanesulfonyl chloride ${ }^{3}$ sometimes has a green colour caused by the presence of dissolved chlorine.

Alkanesulfonyl fluorides are reduced at much more negative cathodic potentials than alkanesulfonyl chlorides. ${ }^{7}$ This is probably the reason for the higher yield of perfluoroalkanesulfonyl fluorides in the case of the ECF of alkanesulfonyl fluorides as a starting material compared to that of the alkanesulfonyl chlorides.

The chlorine radicals and $\mathrm{Cl}_{2}$ that are formed during the electrochemical fluorination of alkanesulfonyl chlorides are chlorinating agents. They make it possible that, in parallel with the Simons process (replacement of hydrogen atoms with fluorine), the chlorination of the starting material and intermediates takes place. The result of both these processes is the formation of chlorofluoro chemicals during the ECF of alkanesulfonyl chlorides in aHF.

Sartori and $\mathrm{Habel}^{8}$ have studied the electrochemical fluorination of $\alpha$-chloroethylsulfonyl chloride and found that the ECF process in this case leads to the formation of a complex mixture of chloro-fluoro chemicals among which fluorinated mono- and di-chloro compounds were identified by means of ${ }^{19} \mathrm{~F}$ NMR spectroscopy. These results indicate that (1) the chlorine atom in the aliphatic chain is replaced during the ECF process with much more difficulty than hydrogen, and (2) the chlorination process takes place in parallel with the Simons process (formation of dichloro derivatives). $\alpha$-Chloroethanesulfonyl chloride contains two kinds of chlorine atoms, making it difficult to determine the source of the chlororadicals that are surely intermediates in the chlorination process.

This is the reason why we have decided to investigate in detail the ECF of ethanesulfonyl chloride in comparison with that of ethanesulfonyl fluoride. The ECF of these two very similar compounds gives drastically different results. Whereas the Simons process with ethanesulfonyl fluoride results in the formation of pentafluoroethanesulfonyl fluoride in $82 \%$ yield, the ECF of ethanesulfonyl chloride gives a complex mixture of perfluorinated and partially fluorinated compounds together with large amounts of chloro-fluoro-ethanes and -sulfonyl fluorides. These results indicate first, that during the ECF of ethanesulfonyl chloride a significant decomposition of the starting material takes place (only $35 \mathrm{~g}$ of fluorinated product from $136.4 \mathrm{~g}$ of starting material was obtained, see Experimental), and second, chlorination of the starting material and intermediates proceeds in parallel with the Simons process. The ${ }^{19} \mathrm{~F}$ NMR investigations of the mixture collected in the trap at $-78^{\circ} \mathrm{C}$ during the ECF of ethanesulfonyl chloride gives the possibility of identifying 40 different compounds that are present in this mixture. All these compounds can be divided into three groups: fluorinated alkanesulfonyl fluorides and chlorides (Table 1); chloro-fluoro ethanes (Tables 2-6) and sulfur-containing side products ( Table 7).

As can be expected, the main product in this mixture is pentafluoroethanesulfonyl fluoride, but only in a proportion of $38 \mathrm{~mol}^{\%}$ (see Table 1).

$\alpha$ - and $\beta$-Chlorotetrafluoroethanesulfonyl fluorides were also found in significant quantity. The formation of these substances is possible only via a chlorination process because the starting molecule of ethanesulfonyl chloride does not contain a chlorine atom at this position. What is the source of chlorine radicals which are intermediates in the chlorinating process? Certainly the starting material, which contains a $\mathrm{S}-\mathrm{Cl}$ bond, is a precursor for the formation of chloro radicals either by reaction with nickel fluorides on the surface of the nickel anode 
Table 1. Compounds containing the $\mathrm{SO}_{2} \mathrm{~F}$ and $\mathrm{SO}_{2} \mathrm{Cl}$ groups.

\begin{tabular}{|c|c|c|}
\hline Formula & $\begin{array}{l}\text { Contents in the } \\
\text { mixture (mol\%) }\end{array}$ & ${ }^{19} \mathrm{~F}$ NMR \\
\hline 1. $\mathrm{CF}_{3} \mathrm{CF}_{2} \mathrm{SO}_{2} \mathrm{~F}$ & 38.1 & $\begin{array}{l}-113.1 \mathrm{~d}\left(2 \mathrm{~F}, \mathrm{CF}_{2}\right) \\
-80.3 \mathrm{~d}\left(3 \mathrm{~F}, \mathrm{CF}_{3}\right) \\
44.9 \mathrm{qt}\left(1 \mathrm{~F}, \mathrm{SO}_{2} \mathrm{~F}\right) \\
J^{4} \mathrm{F,F}=6.8 \mathrm{~Hz} \\
J_{\mathrm{F}, \mathrm{F}}^{3}=6.3 \mathrm{~Hz}\end{array}$ \\
\hline 2. $\mathrm{ClCF}_{2} \mathrm{CF}_{2} \mathrm{SO}_{2} \mathrm{~F}$ & 3.8 & $\begin{array}{l}-107.6 \mathrm{dt}\left(2 \mathrm{~F}_{1} \mathrm{CF}_{2}\right) \\
-67.7 \mathrm{dt}\left(2 \mathrm{~F}, \mathrm{CClF}_{2}\right) \\
46.6 \mathrm{tt}\left(1 \mathrm{~F}, \mathrm{SO}_{2} \mathrm{~F}\right) \\
J^{4}{ }_{\mathrm{F}, \mathrm{F}}=8.0 \mathrm{~Hz} \\
J^{3}=5.5 \mathrm{~Hz} \\
J_{\mathrm{F}, \mathrm{F}}^{3}=2.6 \mathrm{~Hz}\end{array}$ \\
\hline 3. $\mathrm{CF}_{3} \mathrm{CFCISO}_{2} \mathrm{~F}$ & 1.5 & $\begin{array}{l}-122.3 \mathrm{q}(1 \mathrm{~F}, \mathrm{CClF}) \\
-77.3 \mathrm{dd}\left(3 \mathrm{~F}, \mathrm{CF}_{3}\right) \\
42.0 \mathrm{q}\left(1 \mathrm{~F}, \mathrm{SO}_{2} \mathrm{~F}\right) \\
J^{4} \mathrm{~F}, \mathrm{~F}=9.4 \mathrm{~Hz} \\
J_{\mathrm{F}, \mathrm{F}}^{3}=6.8 \mathrm{~Hz}\end{array}$ \\
\hline 4. $\mathrm{CF}_{3} \mathrm{CF}_{2} \mathrm{SO}_{2} \mathrm{Cl}$ & 1.0 & $\begin{array}{l}-109.7 \mathrm{~s}\left(2 \mathrm{~F}, \mathrm{CF}_{2}\right) \\
-78.0 \mathrm{~s}\left(3 \mathrm{~F}, \mathrm{CF}_{3}\right)\end{array}$ \\
\hline 5. $\mathrm{CF}_{3} \mathrm{CHFSO}_{2} \mathrm{~F}$ & 0.1 & $\begin{array}{l}-191.2 \text { dqd }(1 \mathrm{~F}, \mathrm{CHF}) \\
-74.3 \mathrm{ddd}\left(3 \mathrm{~F}, \mathrm{CF}_{3}\right) \\
52.2 \mathrm{qdd}\left(1 \mathrm{~F}, \mathrm{SO}_{2} \mathrm{~F}\right) \\
J^{4}{ }_{\mathrm{F}, \mathrm{F}}=9.5 \mathrm{~Hz} \\
J_{\mathrm{F}, \mathrm{F}}=7.0 \mathrm{~Hz} \\
J_{\mathrm{F}, \mathrm{F}}^{3}=11.4 \mathrm{~Hz} \\
J^{2}{ }_{\mathrm{H}, \mathrm{F}}=44.5 \mathrm{~Hz} \\
J^{3}{ }_{\mathrm{H}, \mathrm{F}}=5.1 \mathrm{~Hz} \\
J_{\mathrm{H}, \mathrm{F}}^{3}=2.3 \mathrm{~Hz}\end{array}$ \\
\hline 6. $\mathrm{CF}_{3} \mathrm{SO}_{2} \mathrm{~F}$ & 0.2 & $\begin{array}{l}-73.0 \mathrm{~d}\left(3 \mathrm{~F}_{,} \mathrm{CF}_{3}\right) \\
37.6 \mathrm{q}\left(1 \mathrm{~F}, \mathrm{SO}_{2} \mathrm{~F}\right) \\
J_{\mathrm{F}, \mathrm{F}}^{3}=18.0 \mathrm{~Hz}\end{array}$ \\
\hline \multirow[t]{2}{*}{ 7. $\mathrm{CF}_{2} \mathrm{ClSO}_{2} \mathrm{~F}$} & 0.2 & $\begin{array}{l}-59.4 \mathrm{~d}\left(2 \mathrm{~F}, \mathrm{CF}_{2} \mathrm{Cl}\right) \\
31.1 \mathrm{t}\left(1 \mathrm{~F}, \mathrm{SO}_{2} \mathrm{~F}\right) \\
J_{\mathrm{F}, \mathrm{F}}^{3}=8.0 \mathrm{~Hz}\end{array}$ \\
\hline & Total $44.9 \mathrm{~mol} \%$ & \\
\hline
\end{tabular}

or by the reduction of sulfonyl chlorides according to eqns. (3) or (4) followed by the anodic oxidation of the chloride anions.

We have studied the electrochemical behaviour of ethanesulfonyl chloride by means of cyclic voltammetry (Fig. 2), and have found that this compound is reduced irreversibly on a glassy carbon electrode at a potential of $-1.34 \mathrm{~V}$ (vs. SCE) [eqn. (5)]. Following a cathodic scan an irreversible wave in the anodic area at the potential of $1.15 \mathrm{~V}$ appeared. The anodic wave reflects the electrochemical oxidation of chloride ions generated in the cathodic process [eqn. (6)].

$$
\begin{aligned}
& \mathrm{C}_{2} \mathrm{H}_{5} \mathrm{SO}_{2} \mathrm{Cl}+2 \mathrm{e} \longrightarrow \mathrm{C}_{2} \mathrm{H}_{5} \mathrm{SO}_{2}{ }^{-}+\mathrm{Cl}^{-} \\
& \mathrm{Cl}^{-}-\mathrm{e} \longrightarrow \mathrm{Cl}^{-}
\end{aligned}
$$

The chlorine radicals generated in this way play a key role in the formation of chlorinated products and the decomposition of the starting material because chloroethanesulfonyl chlorides are reduced more easily than nonchlorinated ones. For example, 2-chloroethanesul-

\begin{tabular}{|c|c|c|}
\hline Formula & $\begin{array}{l}\text { Contents in the } \\
\text { mixture (mol\%) }\end{array}$ & ${ }^{19} \mathrm{~F}$ NMR \\
\hline 1. $\mathrm{CF}_{3} \mathrm{CF}_{3}$ & 0.8 & $-87.0 \mathrm{~s}\left(3 \mathrm{~F}, \mathrm{CF}_{3}\right)$ \\
\hline 2. $\mathrm{CF}_{3} \mathrm{CHF}_{2}$ & 1.1 & $\begin{array}{l}-137.0 \mathrm{~d}\left(2 \mathrm{~F}, \mathrm{CHF}_{2}\right) \\
-86.5 \mathrm{~s}\left(3 \mathrm{~F}, \mathrm{CF}_{3}\right) \\
J_{\mathrm{H}, \mathrm{F}}^{2}=56.0 \mathrm{~Hz}\end{array}$ \\
\hline 3. $\mathrm{CF}_{3} \mathrm{CH}_{2} \mathrm{~F}$ & 1.9 & $\begin{array}{l}-241.0 \mathrm{tq}\left(1 \mathrm{~F}, \mathrm{CH}_{2} \mathrm{~F}\right) \\
-78.3 \mathrm{dt}\left(3 \mathrm{~F}, \mathrm{CF}_{3}\right) \\
J^{3} \mathrm{F,F}=16.0 \mathrm{~Hz} \\
J^{3}{ }_{\mathrm{H}, \mathrm{F}}=8.0 \mathrm{~Hz}\end{array}$ \\
\hline 4. $\mathrm{CF}_{3} \mathrm{CH}_{3}$ & 1.6 & $\begin{array}{l}-61.5 \mathrm{q}\left(3 \mathrm{~F}, \mathrm{CF}_{3}\right) \\
\mathrm{J}_{\mathrm{H}, \mathrm{F}}^{3}=13.0 \mathrm{~Hz}\end{array}$ \\
\hline 5. $\mathrm{CF}_{3} \mathrm{CF}_{2} \mathrm{Cl}$ & 5.8 & $\begin{array}{l}-86.0 \mathrm{~s}\left(3 \mathrm{~F}, \mathrm{CF}_{3}\right) \\
-74.5 \mathrm{~s}\left(2 \mathrm{~F}, \mathrm{CF}_{2} \mathrm{Cl}\right)\end{array}$ \\
\hline 6. $\mathrm{CF}_{3} \mathrm{CCl}_{2} \mathrm{~F}$ & 1.1 & $\begin{array}{l}-84.1 \mathrm{~d}\left(3 \mathrm{~F}, \mathrm{CF}_{3}\right) \\
-77.0 \mathrm{q}\left(1 \mathrm{~F}, \mathrm{CCl}_{2} \mathrm{~F}\right) \\
J_{\mathrm{F}, \mathrm{F}}^{3}=5.5 \mathrm{~Hz}\end{array}$ \\
\hline 7. $\mathrm{CF}_{3} \mathrm{CHClF}$ & 3.4 & $\begin{array}{l}-156.8 \mathrm{dq}(1 \mathrm{~F}, \mathrm{CHCIF}) \\
-82.5 \mathrm{dd}\left(3 \mathrm{~F}, \mathrm{CF}_{3}\right) \\
J^{3}{ }_{\mathrm{F}, \mathrm{F}}=10.3 \mathrm{~Hz} \\
J^{2}=47.0 \mathrm{~Hz} \\
J^{3}{ }_{\mathrm{H}, \mathrm{F}}=4.0 \mathrm{~Hz}\end{array}$ \\
\hline 8. $\mathrm{CF}_{3} \mathrm{CH}_{2} \mathrm{Cl}$ & $\begin{array}{l}3.3 \\
\text { Total } 19.0 \mathrm{~mol} \%\end{array}$ & $\begin{array}{l}-72.4 \mathrm{t}\left(3 \mathrm{~F}, \mathrm{CF}_{3}\right) \\
J_{\mathrm{H}, \mathrm{F}}^{3}=8.0 \mathrm{~Hz}\end{array}$ \\
\hline
\end{tabular}

Table 2. Compounds containing the $\mathrm{CF}_{3}$ group.

fonyl chloride gives the reduction peak in cyclic voltammogram at $-0.99 \mathrm{~V}$ (vs. SCE) (Fig. 3), which is $0.35 \mathrm{~V}$ more positive than the reduction potential of $\mathrm{C}_{2} \mathrm{H}_{5} \mathrm{SO}_{2} \mathrm{Cl}$. Nearly the same difference is found in the reduction potentials of methanesulfonyl chloride and chlorometylsulfonyl chloride (Table 8). This means that, generally, the introduction of a chlorine atom into the aliphatic chain of alkanesulfonyl chlorides shifts the reduction potentials to less negative values. From a practical point of view, the appearance of even traces of chloride anions in the solution during the Simons process (first by the reduction of $\mathrm{C}_{2} \mathrm{H}_{5} \mathrm{SO}_{2} \mathrm{Cl}$ ) triggers the cyclic process: chlorination-reduction-chlorination, which causes a severe decomposition of the starting material during the ECF of ethanesulfonyl chloride. The sulfinic acids which are formed by the cathodic reduction of chloroethanesulfonyl chlorides are not stable during the Simons process. This strongly reduces the yield of desired perfluoroethanesulfonyl fluoride. The instability of chloroethanesulfinic acids, which decompose by elimination of $\mathrm{SO}_{2}$ and other electrochemically active particles, is probably the reason why the reduction current of 2-chloroethanesulfonyl chloride is nearly twice that of $\mathrm{C}_{2} \mathrm{H}_{5} \mathrm{SO}_{2} \mathrm{Cl}$ (Table 8).

$\alpha$ - and $\beta$-Chlorotetrafluoroethanesulfonyl fluorides are formed in parallel with pentafluoroethanesulfonyl fluoride during the $\mathrm{ECF}$ of $\mathrm{C}_{2} \mathrm{H}_{5} \mathrm{SO}_{2} \mathrm{Cl}$. It is remarkable that the yield of $\beta$-chlorotetrafluoroethanesulfonyl fluoride is more than twice as high as that of $\alpha$-chlorotetrafluoroethanesulfonyl fluoride. This means that the chlor- 
Table 3. Compounds containing the $\mathrm{CHF}_{2}$ group.

\begin{tabular}{|c|c|c|}
\hline Formula & $\begin{array}{l}\text { Contents in the } \\
\text { mixture (mol\%) }\end{array}$ & ${ }^{19} \mathrm{~F} \mathrm{NMR}$ \\
\hline 1. $\mathrm{CHF}_{2} \mathrm{CF}_{3}$ & 1.1 & Table 2 \\
\hline 2. $\mathrm{CHF}_{2} \mathrm{CHF}_{2}$ & 0.6 & $\begin{array}{l}-138.7 \mathrm{~d}\left(\mathrm{CHF}_{2}\right) \\
J^{2}{ }_{\mathrm{H}, F}=52.0 \mathrm{~Hz}\end{array}$ \\
\hline 3. $\mathrm{CHF}_{2} \mathrm{CH}_{2} \mathrm{~F}$ & 0.6 & $\begin{array}{l}-130.1 \mathrm{ddt}\left(\mathrm{CHF}_{2}\right) \\
J^{3}{ }_{\mathrm{F}, \mathrm{F}}=16.0 \mathrm{~Hz} \\
J_{\mathrm{H}, \mathrm{F}}^{2}=55.0 \mathrm{~Hz} \\
J^{3}{ }_{\mathrm{H}, \mathrm{F}}=13.0 \mathrm{~Hz}\end{array}$ \\
\hline 4. $\mathrm{CHF}_{2} \mathrm{CH}_{3}$ & 1.1 & $\begin{array}{l}-109.9 \mathrm{dq}\left(\mathrm{CHF}_{2}\right) \\
J^{2}{ }_{\mathrm{H}, \mathrm{F}}=58.0 \mathrm{~Hz} \\
J^{3}{ }_{\mathrm{H}, \mathrm{F}}=21.0 \mathrm{~Hz}\end{array}$ \\
\hline 5. $\mathrm{CHF}_{2} \mathrm{CF}_{2} \mathrm{Cl}$ & 3.4 & $\begin{array}{l}-133.2 \mathrm{dt}\left(2 \mathrm{~F}, \mathrm{CHF}_{2}\right) \\
-73.7 \mathrm{td}\left(2 \mathrm{~F}, \mathrm{CF}_{2} \mathrm{Cl}\right) \\
J^{3}{ }_{\mathrm{F}, \mathrm{F}}=7.0 \mathrm{~Hz} \\
J^{2}{ }_{\mathrm{H}, \mathrm{F}}=54.0 \mathrm{~Hz} \\
J_{\mathrm{H}, \mathrm{F}}^{3}=2.3 \mathrm{~Hz}\end{array}$ \\
\hline 6. $\mathrm{CHF}_{2} \mathrm{CCl}_{2} \mathrm{~F}$ & 0.6 & $\begin{array}{l}-127.5 \mathrm{dd}\left(2 \mathrm{~F}, \mathrm{CHF}_{2}\right) \\
-67.3 \mathrm{dt}\left(1 \mathrm{~F}, \mathrm{CCl}_{2} \mathrm{~F}\right) \\
J^{3} \mathrm{F,F}=14.0 \mathrm{~Hz} \\
J^{2}{ }_{\mathrm{H}, \mathrm{F}}=54.6 \mathrm{~Hz} \\
J_{\mathrm{H}, \mathrm{F}}^{3}=3.5 \mathrm{~Hz}\end{array}$ \\
\hline 7. $\mathrm{CHF}_{2} \mathrm{CHCIF}$ & 3.4 & 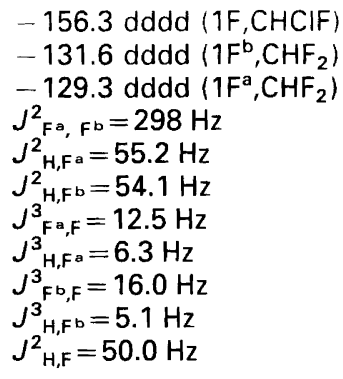 \\
\hline 8. $\mathrm{CHF}_{2} \mathrm{CH}_{2} \mathrm{Cl}$ & 0.8 & $\begin{array}{l}-120.3 \mathrm{dt}\left(\mathrm{CHF}_{2}\right) \\
J^{2}{ }_{\mathrm{H}, \mathrm{F}}=55.0 \mathrm{~Hz} \\
J_{\mathrm{H}, \mathrm{F}}^{3}=13.0 \mathrm{~Hz}\end{array}$ \\
\hline 9. $\mathrm{CHF}_{2} \mathrm{CHCl}_{2}$ & $\begin{array}{l}<0.1 \\
\text { Total } 10.6 \mathrm{~mol} \%\end{array}$ & $\begin{array}{l}-123.8 \mathrm{dd}\left(\mathrm{CHF}_{2}\right) \\
J^{2}{ }_{\mathrm{H}, \mathrm{F}}=56.0 \mathrm{~Hz} \\
J_{\mathrm{H}, \mathrm{F}}^{3}=7.0 \mathrm{~Hz}\end{array}$ \\
\hline
\end{tabular}

ination process preferably takes place at the $\beta$-position of the starting molecule of ethanesulfonyl chloride. In any case, the total yields of these two chlorinated sulfonyl fluorides are much less than that of $\mathrm{C}_{2} \mathrm{~F}_{5} \mathrm{SO}_{2} \mathrm{~F}$ (Table 1). The direct or indirect cathodic reduction of chloroethanesulfonyl chlorides strongly decreases the probability that these molecules survive during the Simons process.

The formation of $\mathrm{C}_{2} \mathrm{~F}_{5} \mathrm{SO}_{2} \mathrm{Cl}$ (Table 1) by the ECF of $\mathrm{C}_{2} \mathrm{H}_{5} \mathrm{SO}_{2} \mathrm{Cl}$ indicates that the $\mathrm{S}-\mathrm{Cl}$ bond can remain untouched during the Simons process. It is also possible that $\mathrm{C}_{2} \mathrm{~F}_{5} \mathrm{SO}_{2} \mathrm{Cl}$ is formed by the reaction of $\mathrm{C}_{2} \mathrm{~F}_{5} \mathrm{SO}_{2} \mathrm{~F}$ with the mixed $\mathrm{Ni}(\mathrm{ClF})_{x}$ on the surface of the nickel anode.

Decomposition of chloroethanesulfonyl chlorides during the ECF process leads to the formation of a large amount of chlorinated fluoroethanes. The total amount of these substances in the mixture trapped at $-78^{\circ} \mathrm{C}$ is
Table 4. Compounds containing the $\mathrm{CF}_{2} \mathrm{Cl}$ group.

\begin{tabular}{|c|c|c|}
\hline Formula & $\begin{array}{l}\text { Contents in the } \\
\text { mixture (mol\%) }\end{array}$ & ${ }^{19} \mathrm{~F}$ NMR \\
\hline 1. $\mathrm{CF}_{2} \mathrm{ClCF}_{3}$ & 5.8 & Table 2 \\
\hline 2. $\mathrm{CF}_{2} \mathrm{ClCHF}_{2}$ & 3.4 & Table 3 \\
\hline 3. $\mathrm{CF}_{2} \mathrm{ClCH}_{2} \mathrm{~F}$ & 1.6 & $\begin{array}{l}-226.1 \mathrm{tt}\left(1 \mathrm{~F}, \mathrm{CH}_{2} \mathrm{~F}\right) \\
-66.9 \mathrm{dt}\left(2 \mathrm{~F}, \mathrm{CF}_{2} \mathrm{Cl}\right) \\
J^{3}{ }_{\mathrm{F}, \mathrm{F}}=20.6 \mathrm{~Hz} \\
J^{2}{ }_{\mathrm{H}, \mathrm{F}}=46.5 \mathrm{~Hz} \\
J_{\mathrm{H}, \mathrm{F}}=10.0 \mathrm{~Hz}\end{array}$ \\
\hline 4. $\mathrm{CF}_{2} \mathrm{ClCH}_{3}$ & $<0.1$ & $\begin{array}{l}-47.6 \mathrm{q}\left(\mathrm{CF}_{2} \mathrm{Cl}\right) \\
J_{\mathrm{H}, \mathrm{F}}^{3}=8.0 \mathrm{~Hz}\end{array}$ \\
\hline 5. $\mathrm{CF}_{2} \mathrm{ClCF}_{2} \mathrm{Cl}$ & 1.7 & $-70.9 \mathrm{~s}\left(\mathrm{CF}_{2} \mathrm{Cl}\right)$ \\
\hline 6. $\mathrm{CF}_{2} \mathrm{ClCHFCl}$ & 1.1 & 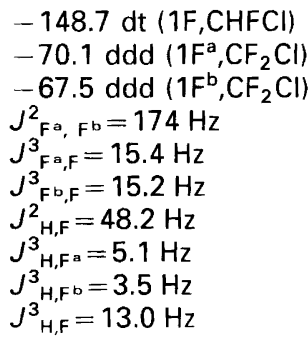 \\
\hline 7. $\mathrm{CF}_{2} \mathrm{ClCH}_{2} \mathrm{Cl}$ & $\begin{array}{l}1.0 \\
\text { Total } 14.6 \mathrm{~mol} \%\end{array}$ & $\begin{array}{l}-59.6 \mathrm{t}\left(\mathrm{CF}_{2} \mathrm{Cl}\right) \\
J_{\mathrm{H}, \mathrm{F}}^{3}=11.0 \mathrm{~Hz}\end{array}$ \\
\hline
\end{tabular}

Table 5. Compounds containing the $\mathrm{CCl}_{2} \mathrm{~F}$ group.

\begin{tabular}{lll}
\hline Formula & $\begin{array}{l}\text { Contents in the } \\
\text { mixture }(\mathrm{mol} \%)\end{array}$ & ${ }^{19} \mathrm{~F} \mathrm{NMR}$ \\
\hline 1. $\mathrm{CCl}_{2} \mathrm{FCF}_{3}$ & 1.1 & Table 2 \\
2. $\mathrm{CCl}_{2} \mathrm{FCHF}_{2}$ & 0.6 & Table 3 \\
3. $\mathrm{CCl}_{2} \mathrm{FCH}_{2} \mathrm{~F}$ & $<0.1$ & $-210.8 \mathrm{td}\left(1 \mathrm{~F}, \mathrm{CH}_{2} \mathrm{~F}\right)$ \\
& & $-73.0 \mathrm{~d}\left(1 \mathrm{~F}, \mathrm{CCl}_{2} \mathrm{~F}\right)$ \\
& & $J^{3} \mathrm{F,F}=21.5 \mathrm{~Hz}$ \\
& & $J^{2}{ }_{\mathrm{H}, \mathrm{F}}=47.3 \mathrm{~Hz}$ \\
& & $-46.1 \mathrm{q}\left(\mathrm{CCl}_{2} \mathrm{~F}\right)$ \\
4. $\mathrm{CCl}_{2} \mathrm{FCH}_{3}$ & 1.4 & $J^{3}{ }_{\mathrm{H}, \mathrm{F}}=20,6 \mathrm{~Hz}$ \\
& & $-139.9 \mathrm{dd}(1 \mathrm{~F}, \mathrm{CHFCl})$ \\
5. $\mathrm{CCl}_{2} \mathrm{FCHFCl}$ & $<0.1$ & $-69.4 \mathrm{~d}\left(1 \mathrm{~F}, \mathrm{CCl}{ }_{2} \mathrm{~F}\right)$ \\
& & $J^{3}{ }_{\mathrm{F}, \mathrm{F}}=22.0 \mathrm{~Hz}$ \\
& & $J^{2}{ }_{\mathrm{H}, \mathrm{F}}=48.4 \mathrm{~Hz}$ \\
\hline
\end{tabular}

$29.4 \mathrm{~mol} \%$, consisting mostly of monochlorinated compounds $(22.0 \mathrm{~mol} \%)$. The amount of fluorinated dichloroethanes is $7.2 \mathrm{~mol} \%$ and that of trichloroethanes is less than $0.2 \mathrm{~mol} \%$. These figures clearly indicate that the introduction of even one chlorine atom into the aliphatic chain is sufficient to cause severe decomposition of the starting material during the ECF process.

The formation of large amounts of sulfur-containing side products (Table 7) indicates that the $\mathrm{C}-\mathrm{S}$ bond is also a weak part of the starting molecule. The cleavage of this bond is probably accelerated by the introduction 
Table 6. Compounds containing the $\mathrm{CHFCl}$ group.

\begin{tabular}{|c|c|c|}
\hline Formula & $\begin{array}{l}\text { Contents in the } \\
\text { mixture (mol\%) }\end{array}$ & ${ }^{19} \mathrm{~F}$ NMR \\
\hline 1. $\mathrm{CHFClCF}_{3}$ & 3.4 & Table 2 \\
\hline 2. $\mathrm{CHFClCHF}_{2}$ & 2.3 & Table 3 \\
\hline 3. $\mathrm{CHFClCH}_{2} \mathrm{~F}$ & $<0.1$ & $\begin{array}{l}-220.3 \mathrm{tdd}\left(1 \mathrm{~F}, \mathrm{CH}_{2} \mathrm{~F}\right) \\
-146.6 \mathrm{dm}(1 \mathrm{~F}, \mathrm{CHFCl}) \\
J^{2}{ }_{\mathrm{H}, \mathrm{F}}=47.3 \mathrm{~Hz} \\
J^{2}{ }_{\mathrm{H}, \mathrm{F}}=40.5 \mathrm{~Hz} \\
J^{3} \mathrm{H}=8.6 \mathrm{~Hz} \\
J_{\mathrm{H}, \mathrm{F}}^{3}=19.3 \mathrm{~Hz}\end{array}$ \\
\hline 4. $\mathrm{CHFClCH}_{3}$ & $<0.1$ & $\begin{array}{l}-135.4 \mathrm{dq}(\mathrm{CHFCl}) \\
J^{2}{ }_{\mathrm{H}, \mathrm{F}}=52.0 \mathrm{~Hz} \\
J_{\mathrm{H}, \mathrm{F}}=8.0 \mathrm{~Hz}\end{array}$ \\
\hline 5. $\mathrm{CHFClCF}_{2} \mathrm{Cl}$ & 1.1 & Table 4 \\
\hline 6. $\mathrm{CHFClCFCl}_{2}$ & $<0.1$ & Table 5 \\
\hline 7. $\mathrm{CHFClCHCl}{ }_{2}$ & $<0.1$ & $\begin{array}{l}-137.3 \mathrm{dd}(\mathrm{CHFCl}) \\
J^{2}{ }_{\mathrm{H}, \mathrm{F}}=55.0 \mathrm{~Hz} \\
J_{\mathrm{H}, \mathrm{F}}=7.0 \mathrm{~Hz}\end{array}$ \\
\hline 8. $\mathrm{CHFClCH}_{2} \mathrm{Cl}$ & Total $7.3 \mathrm{~mol} \%$ & $\begin{array}{l}-137.9 \text { ddd (CHFCl) } \\
J^{2}{ }_{H, F}=5.0 \mathrm{~Hz} \\
J^{3}{ }_{H, F}=12.5 \mathrm{~Hz} \\
J^{3}{ }_{H, F}=22.8 \mathrm{~Hz}\end{array}$ \\
\hline
\end{tabular}

Table 7. Sulfur-containing side-products.

\begin{tabular}{lcr}
\hline Formula & Contents in the mixture $(\mathrm{mol} \%)$ & ${ }^{19} \mathrm{~F} \mathrm{NMR}$ \\
\hline 1. $\mathrm{SO}_{2} \mathrm{~F}_{2}$ & 10.7 & $+33.3 \mathrm{~s}$ \\
2. $\mathrm{SOF}_{2}$ & 3.8 & $+74.5 \mathrm{~s}$ \\
3. $\mathrm{SSF}_{2}$ & 5.0 & $+79.7 \mathrm{~s}$ \\
4. $\mathrm{SF}_{6}$ & $<0.1$ & $+59.6 \mathrm{~s}$ \\
5. $\mathrm{SOF}_{4}$ & $<0.1$ & $+100.0 \mathrm{~s}$ \\
& Total $19.7 \mathrm{~mol} \%$ & \\
\hline
\end{tabular}

Table 8. Reduction potentials of alkanesulfonyl chlorides.

\begin{tabular}{llc}
\hline Formula & $E_{\mathrm{p}}^{\text {red }} / \mathrm{V}$ vs. SCE & $I_{\mathrm{p}} / \mu \mathrm{A}$ \\
\hline 1. $\mathrm{CH}_{3} \mathrm{SO}_{2} \mathrm{Cl}$ & -1.30 & 105 \\
2. $\mathrm{ClCH}_{2} \mathrm{SO}_{2} \mathrm{Cl}$ & -0.90 & 190 \\
3. $\mathrm{CH}_{3} \mathrm{CH}_{2} \mathrm{SO}_{2} \mathrm{Cl}$ & -1.34 & 184 \\
4. $\mathrm{ClCH}_{2} \mathrm{CH}_{2} \mathrm{SO}_{2} \mathrm{Cl}$ & -0.99 & 332 \\
\hline
\end{tabular}

Concentration of substrate: $2 \times 10^{-3} \mathrm{M}$. Electrode: glassy carbon. Supporting electrolyte: $0.1 \mathrm{M}$ tetrabutylammonium tetrafluoroborate in $\mathrm{CH}_{3} \mathrm{CN}$. Reference electrode: SCE $\left(E_{\mathrm{p}}^{\text {ox }}\right.$ ferrocene $=0.425 \mathrm{~V}$ ). Scan rate: $0.2 \mathrm{~V} \mathrm{~s}^{-1}$.

of a chlorine atom into $\alpha$-position of the starting molecule.

The cleavage of the $\mathrm{C}-\mathrm{C}$ bond during the ECF of $\mathrm{C}_{2} \mathrm{H}_{5} \mathrm{SO}_{2} \mathrm{Cl}$ is not a process of significant importance because the yield of $\mathrm{CF}_{3} \mathrm{SO}_{2} \mathrm{~F}$ and $\mathrm{ClCF}_{2} \mathrm{SO}_{2} \mathrm{~F}$ is very low (Table 1). The influence of this process on the yield of $\mathrm{C}_{2} \mathrm{~F}_{5} \mathrm{SO}_{2} \mathrm{~F}$ is even less in the case of the ECF of ethanesulfonyl fluoride.

The results presented in this paper show that the large difference in the yield of $\mathrm{C}_{2} \mathrm{~F}_{5} \mathrm{SO}_{2} \mathrm{~F}$ produced by means

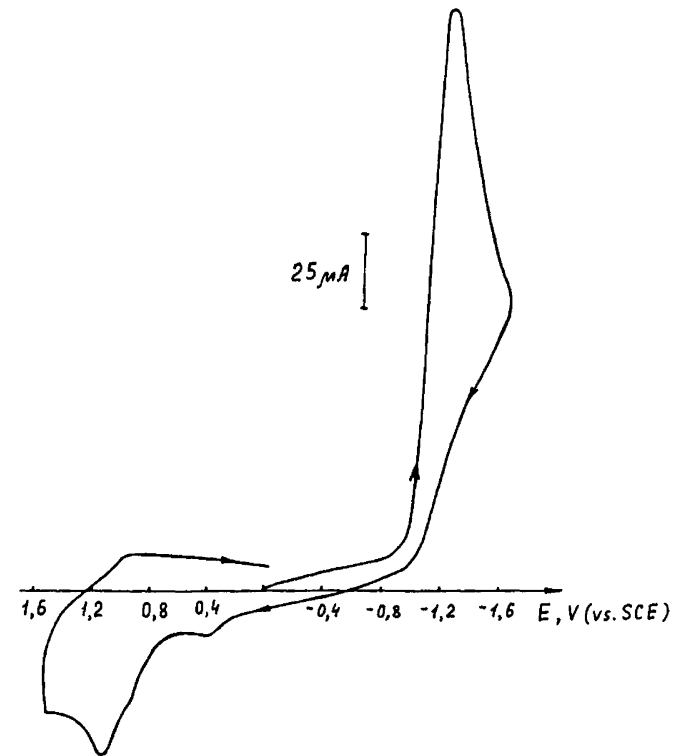

Fig. 2. Cyclic voltammogram of ethanesulfonyl chloride. Concentration: $2 \times 10^{-3} \mathrm{M}$. Electrode: glassy carbon. Supporting electrolyte: $0.1 \mathrm{M}$ tetrabutylammonium tetrafluoroborate in $\mathrm{CH}_{3} \mathrm{CN}$. Scan rate: $0.2 \mathrm{~V} \mathrm{~s}^{-1}$.

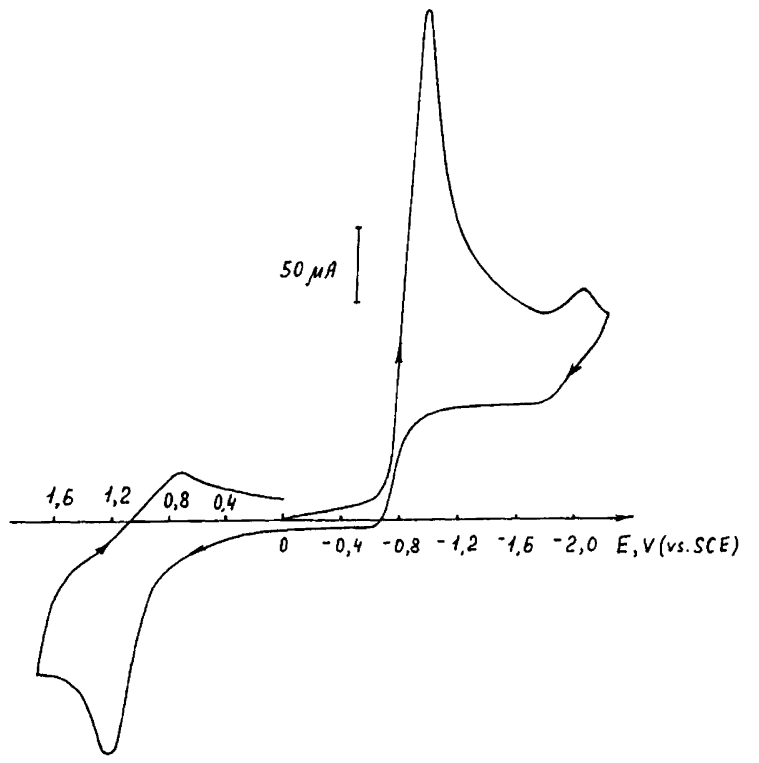

Fig. 3. Cyclic voltammogram of 2-chloroethanesulfonyl chloride. Concentration: $2 \times 10^{-3} \mathrm{M}$. Electrode: glassy carbon. Supporting electrolyte: $0.1 \mathrm{M}$ tetrabutylammonium tetrafluoroborate in $\mathrm{CH}_{3} \mathrm{CN}$. Scan rate: $0.2 \mathrm{~V} \mathrm{~s}^{-1}$.

of the Simons process from $\mathrm{C}_{2} \mathrm{H}_{5} \mathrm{SO}_{2} \mathrm{Cl}$ or $\mathrm{C}_{2} \mathrm{H}_{5} \mathrm{SO}_{2} \mathrm{~F}$ as a starting material is determined by the chlorination process which takes place during the ECF of ethanesulfonyl chloride. The difference in yield for $\mathrm{CF}_{3} \mathrm{SO}_{2} \mathrm{~F}$ is much less by the ECF of $\mathrm{CH}_{3} \mathrm{SO}_{2} \mathrm{Cl}$ or $\mathrm{CH}_{3} \mathrm{SO}_{2} \mathrm{~F}$ (only $10-20 \%$ ) because in this case the way to the perfluorinated molecule is much shorter and the probability of chlorination during the ECF of methanesulfonyl chloride is much lower.

The investigation of the product distribution pattern 
during the ECF of ethanesulfonyl chloride and fluoride makes it possible to optimise this process and develop the technology for the industrial production of pentafluoroethane sulfonic acid.

Acknowledgement. A. Kucherina thanks Chemikalien Klaus F. Meyer GmbH (Germany) for financial support of this work.

\section{References}

1. Alsmeyer, Y. W., Childs, W. V., Flynn, R. M., Moor, G. G. I. and Smeltzer, J. C. In: Banks, R. E., Smart, B. E. and Tatlow, J. C., Eds., Organofluorine Chemistry, Plenum Press, New York 1994, Chap. 5.

2. Sartori, P. and Ignat'ev, N. J. Fluorine Chem. 87 (1998) 157.
3. Gramstad, T. and Haszeldine, R. N. J. Chem. Soc. (1956) 173; Shopen, V., Sapozhnikov, M., Lvov, V., Varfalameev, L., Turnaev, M., Cherviachkov, Yu., Yurochkin, V. and Ignat'ev, N. 11th European Symposium on Fluorine Chemistry, Bled, Slovenia, 1722 September 1995, Abstracts, p. 90.

4. Gramstad, T. and Haszeldine, R. N. J. Chem. Soc. (1957) 2640.

5. Ignat'ev, N. V., Datsenko, S. D., Pasenok, S. V. and Yagupolskii, L. M. Zh. Org. Khim. 26 (1990) 1740.

6. Prokop, H. W., Zhou, H.-J., Xu, S.-Q., Wu, C.-H., Chuey, S. R. and Liu, C. C. J. Fluorine Chem. 43 (1989) 257.

7. Lund, H. In: Baizer, M. M. and Lund, H., Eds., Organic Electrochemistry', 2nd edn., Marcel Dekker, New York 1983. Chap. 22, Part B.

8. Sartori, P. and Habel, W. J. Fluorine Chem. 18 (1981) 131.

Received 25 January 1999. 